\title{
弾性波を利用する岩盤監視*
}

\author{
佐々宏 $-^{1}$ 南光宣 和 ${ }^{2}$ \\ 渋 江 隆 雄 $^{3}$
}

1. 緒

言

岩艋監視は鉱柱採掘や地下貯蔵庫, 地下発電所などの大 空洞を開さくする時のみならず, ほとんどすべての岩盤構 造物の安定性を評価する場合に必要となる事項の一つであ る。岩盤監視法としては, 弾性波を利用する方法, 微小破 壊音 (Acoustic emission略してAE と呼ぶ)を用いる 方法, 比抵抗電気探査を用いる方法などが考元られる。筆 者らは数年前より, 岩石試料の剛性圧縮破壊試験を実施し, 試料が破壊にいたるまでのひずみ变化, 弾性波伝播速度変 化, 弾性波の伝播にともなう振幅の減衰状態の変化, $\mathrm{A} \mathrm{E}$ の発生状況などを測定し，これらの測定結果を検討するこ とによつて, 新たなき裂の発生および既存のき裂の幅の変 化の検出には, 弾性波の伝播にともなう振幅の減衰状態の 変化を測定するという方法が簡単であり, かつ, 検出感度 が良好な方法であるという結論を得た。

そこで, 現場に扔いてこの方法を用いて岩盤監視を行な うための最適な計測システムについて検討するとともに， この方法を用いて鉱柱採掘現場の天盤の監視を行なつたの で, それらの結果について報告する。

\section{2. 岩盤監視システム}

岩盤監視を行ないたい区域の両側に測点(1)および(2)を定 め, これらの測点に振動ピックアップを設置する。ついで, 測点(1)近くに発振点を設け, この点を打撃するか, それ ともその点で爆薬を爆発させて波動を岩盤内一送り込み， その波動が測点(1)よび(2)に到達したことによつて発生す るそれぞれの点の岩艋粒子の振動を振動ピックアップを用 いて測定する。測点(1)に発生した振動の振幅は, 調查区域 へ送り込まれた波動の振幅に対応しており, 測点(2に発生 した振動の振幅は調查区域を通過してきた波動の振幅に対 応している。したがつて, 測点(2)到達する波動の伝播径 路を横切る方向に新たなき裂が発生した場合や, その方 にすでに存在していたき裂の厚さ, 幅, 長さのいずれかが 増大した場合には, 測点(2) 到達する波動の振幅が低下す

* 1981 年 7 月 28 日受理

1. 正会員 工博 京都大学助教授 工学部資源工学科

2. 正会員 三井金属鉱業株式会社神岡鉱業所副所長

3. 正会員 三井金属鉱業株式会社神岡鉱業所栃洞鉱

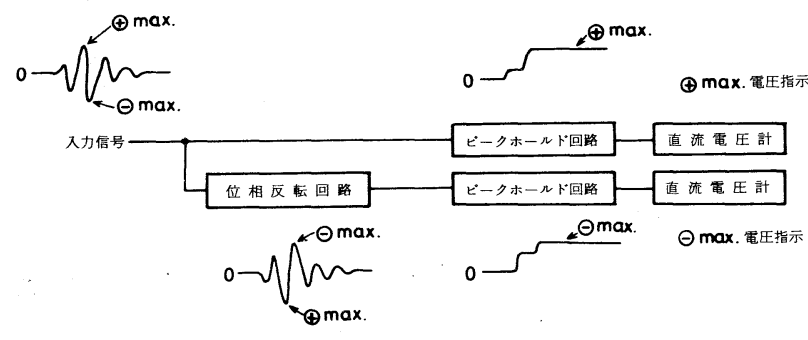

第 1 図 最大振幅測定方法説明図

る。したがつて, 測点(1)に発生した振動の振幅最高値 $a_{1}$ と測点(2に発生した振動の振幅最高値 $a_{2}$ とを測定し, それ らの比 $\left(a_{2} / a_{1}\right)$ の值を検討することによつて, 岩盤監視を 行なうことができる。

さて, 打撃や爆薬の爆発によつて岩艋内へ投射される波 動による岩盤粒子の振動波形は, 第 1 図に入力信号として 示したように，振幅が時間とともに変化する継続時間の短 かい波形である。通常, このような信号の最大振幅を測定 したい場合には, オシログラフを用いて振動ピックアップ の出力電圧を記録紙に画かせ，その波形の最大振幅を読み 取るといら方法が用いられている。しかし，このような方 法ではオシログラフを測定現場に持ち込まねばならず, $\mathrm{AC} 100 \mathrm{~V}$ 電源も必要となる場合が多い。したがつて, $\mathrm{AC}$ 電源の配線や重、測定器の移動が困難で, かつ, 湿度 の高い坑内などの条件の悪、現場で岩盤監視を行なう計測 システムとしては, 乾電池電源の小型軽量の測定器を用い る簡単な計測システムが要求される。

今回採用した計測システムでは, 第 1 図に示すように, 振動ピックアップの出力信号 (最大振幅測定器への入力信 号）を分岐させ，その一つを位相反転回路に入れて位相を 反転させ，この両者をピークホールド回路へ入れる。こう すると，位相を反転させていない信号を入力したピークホ ールド回路の出力は入力信号の正の最大電圧と同じ大きさ の正の直流電圧となり，位相反転回路を通つた信号を入力 したピークホールド回路の出力は, 負の最大電圧と同じ大 きさの正の直流電圧となる。したがつて，この両者を直流 電圧計で読み取れば, ピックアップの出力信号の正の最大 值と負の最大値とを読み取ることができる。なお,このよ うな計測システムが現場計測に際して有効なことは, 先に 実施した小規模な現場計測において確認している。 

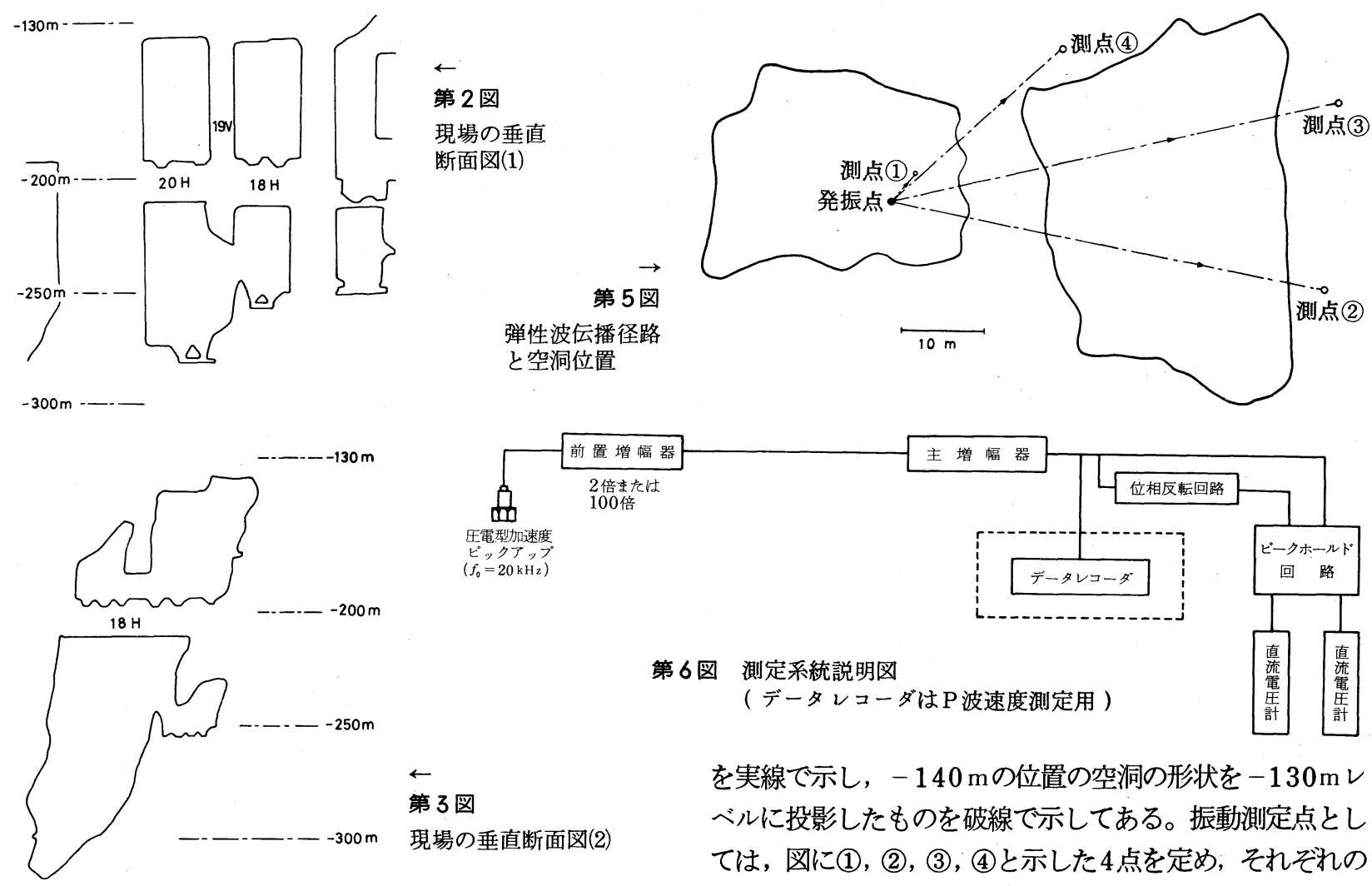

現場の垂直断面図(2)

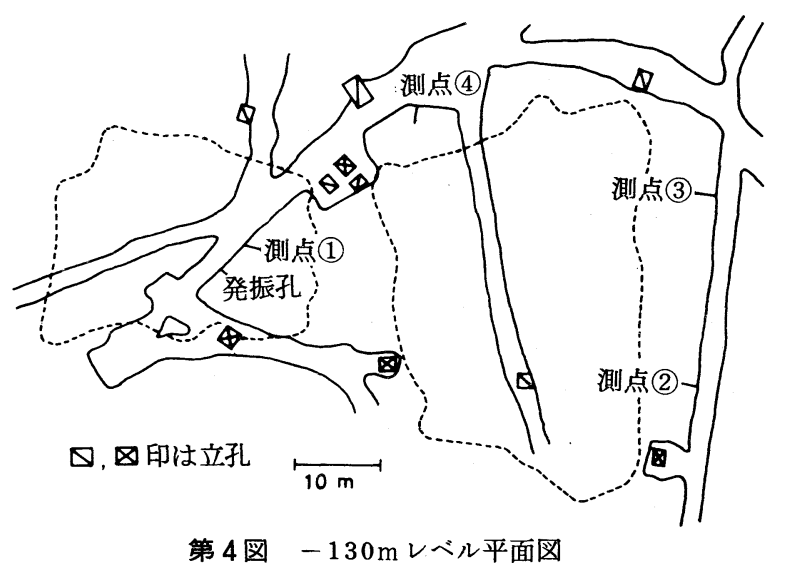

3. 現場の状況と測定方法

三井金属鉱業 (株) 神岡鉱業所栃洞鉱において, 鉱柱採掘 を行なう現場の空洞天盤の岩盤監視を上記の方法で行なつ た。第 2 図は採掘しようとしている垂直鉱柱を横切る方向 の垂直断面図であり，第 3 図は第 2 図に示した断面に直交 する方向の垂直断面図である。採掘の対象となつている鉱 柱は図に $18 \mathrm{H}, 20 \mathrm{H}$ と記したー $200 \mathrm{~m}$ レベルにある水平 鉱柱全部と，19V と記した垂直鉱柱の- $170 \mathrm{~m}$ レベル以 下の部分とである。岩盤監視は既に一次採掘て鉱石が採掘

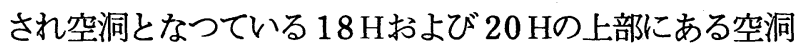
の天盤から約 $10 \mathrm{~m}$ 上の- $130 \mathrm{~m}$ レベルにある坑道を利用 して行なつた。なお，地表はー $130 \mathrm{~m}$ レベルの上約 $150 \mathrm{~m}$ の位置にある。

第 4 図は $-130 \mathrm{~m}$ レベルの平面図であつて, 坑道の状態

を実線で示し， $-140 \mathrm{~m}$ の位置の空洞の形状を $-130 \mathrm{~m}$ V ベルに投影したものを破線で示してある。振動測定点とし ては, 図に(1), (2), (3), (4)と示した4点を定め; それぞれの 地点の坑道壁面から図に示すように長さ $2.5 \mathrm{~m}$ の孔を穿孔 し, その孔底に圧電型加速度ピックアップをセメントモル タルを用いて埋め込んだ。このように振動ピックアップを 岩艋内部に埋め込んだのは, その坑道を掘さくしたときの 発破などで坑道近傍に発生している既存のきれつの影響を 除外するためと, ピックアップの設置条件が長期にわたつ て変動しないようにするためである。発振点としては, 測 点(1より約 $8 \mathrm{~m}$ 離れた地点を選び，坑道壁面から $2.0 \mathrm{~m}$ 穿 孔した孔の孔底で $40 \mathrm{~g}$ の 3 号桐ダイナマイトを爆発させて 波動を岩盤内へ送り込んだ。 $50 \mathrm{~g}$ 程度の少量の爆薬を岩盤 内で爆発させた場合に発生する波動の卓越周波数は $1 \sim 5$ $\mathrm{kHz}$ 程度であるから振動ピックアップとしては固有振動数 が $20 \mathrm{kHz}$ の小型の圧電型加速度ピックアップを用いた。

第 5 図は各測点へ到達する波動の伝播径路と空洞位置と の関係を示した図である。罒に示すように今回の測定では, 測点(1)で調查区域内一送り込まれる波動の振幅を測定し， 測点(2)，(3)，(4)で調査区域を通過してきた波動の振幅を測 定していることになる。

第6罒は，使用した測定系統を示したものである。図に 示すように今回は波動の振幅の伝播にともなう减衰状態の 変化を測定するとともに, 各測点の振動ピックアップの出 力信号をデータレコーダを用いて記録し, それを解析室で 再生することによつて, 各測点の振動波形と各測点一到達 した波動の伝播速度（P波速度）を求め, 振幅の減衰状態 の変化と対比して検討することにした。

鉱柱を長孔発破によつて採掘回収する作業は, 昭和54年 4 月 23 日から開始された。作業はまず，水平鉱柱 $18 \mathrm{H}$ の 
$-200 \mathrm{~m}$ レベルより下の鉱石を採掘する作業から始められ, 採掘, 鉱石抽出, 土砂投入を繰り返しながら進行し, 昭和 55 年 4 月末までに水平鉱柱 $18 \mathrm{H}, 20 \mathrm{H}$ の全部と, 垂直 鉱柱 $19 \mathrm{~V}$ の約 $-170 \mathrm{~m}$ の位置より下の部分とが採掘され た。その後, 昭和 55 年 7 月末までに空洞内一約 50,000 $\mathrm{m}^{3}$ の土砂が投入され,土砂の上面と空洞天盤との間にほぼ $40 \mathrm{~m}$ の高さの空間を残す状態となつている。

$\mathrm{P}$ 波伝播速度および波動の振幅の測定は昭和 53 年 12 月 より開始したが，振幅の減衰状態に関しては昭和 53 年 12 月および昭和 54 年 3 月に実施した 2 回の測定で測定方法 および測定器の調整を行なつたのち, 昭和 54 年 7 月 12 日 より本格的な測定を開始した。振幅の測定に際しては，同 一日に発振孔内で約 10 回爆薬を爆発させて各測点に発生 した振動の正のピーク値と負のピーク値とを読み取り，そ の和の平均値をその測定日の各測点の最大振幅とした。波 動の伝播にともなう振幅の减衰状態を評価する基準として, 昭和 54 年 7 月 12 日に測定した測点(2), (3), (4)の振幅と測 点(1)の振幅との比
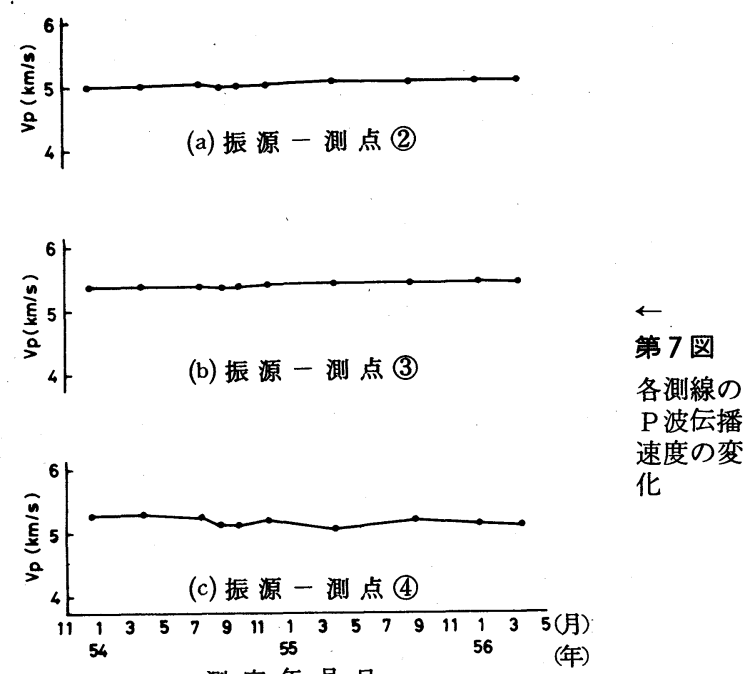

速度の変 化

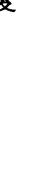

$$
\begin{aligned}
& \left(a_{2}(7 / 12) / a_{1}(7 / 12)\right) \equiv A_{02} \\
& \left(a_{3}(7 / 12) / a_{1}(7 / 12)\right) \equiv A_{03} \\
& \left(a_{4}(7 / 12) / a_{1}(7 / 12)\right) \equiv A_{04}
\end{aligned}
$$

を採用し, その後の測定で得られた

$$
\begin{aligned}
& \left(a_{2} / a_{1}\right) \equiv A_{2}, \quad\left(a_{3} / a_{1}\right) \equiv A_{3}, \\
& \left(a_{4} / a_{1}\right) \equiv A_{4} \text { の值之上記の基準値との比 } A_{2} / A_{0},
\end{aligned}
$$

$A_{3} / A_{0}, A_{4} / A_{0}$ で波動の伝播にともなう振幅の減衰状態 を評価することにした。

\section{4. 測 定 結 果}

第 7 図は測点(2), (3), (4)へ入射した波動の伝播速度の経 時変化を示したものである。図より，-130 mレベルの岩 艋内の $\mathrm{P}$ 波速度は, 測点(4一入射する波動に関してはやや 低下している傾向は認められるものの, 全体としてみれば, 昭和 53 年 12 月から昭和 56 年 3 月までの 2 年以上の間ほ とんど変化していないことがわかる。

第 8 図は $A_{2} / A_{02}, A_{3} / A_{03}, A_{4} / A_{04}$ の值の経時变化を示 したものである。図より， $A / A_{0}$ の值は水平鉱柱の採掘が 進行していた昭和 54 年 12 月頃より低下しはじめ, 水平鉱 柱全部と垂直鉱柱の約 $-170 \mathrm{~m}$ より下が無くなつた昭和 55 年 4 月末で $A_{2} / A_{02}$ は $0.7, A_{3} / A_{03}$ および $A_{4} / A_{04}$ はとも に 0.58 まで低下し,その後しばらくほぼ同じ割合で低下 を続けているが，土砂充埧がほぼ完了した昭和 55 年 8 月 以降は低下の割合が少なくなつており, 岩盤が安定してき ていることを示している。

第 9 図は振幅比の基準として採用した昭和 54 年 7 月 12 日に行なつた測定で得られた各測点の振動波形の一例を示

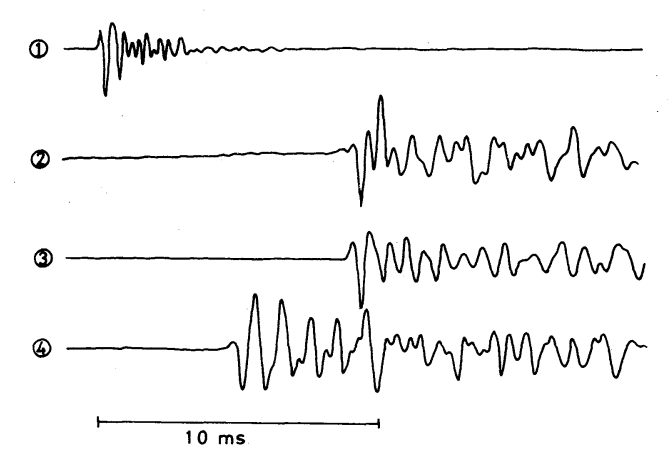

第 8 図

振幅の伝播にともなら 減衰状態の経時变化
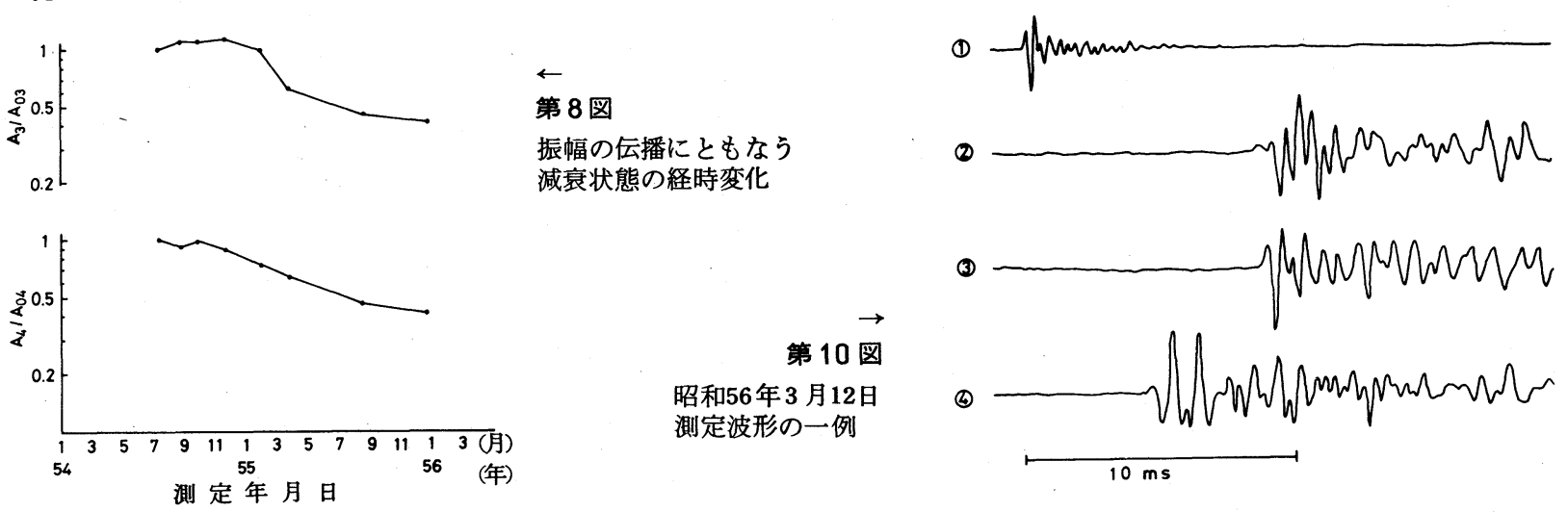

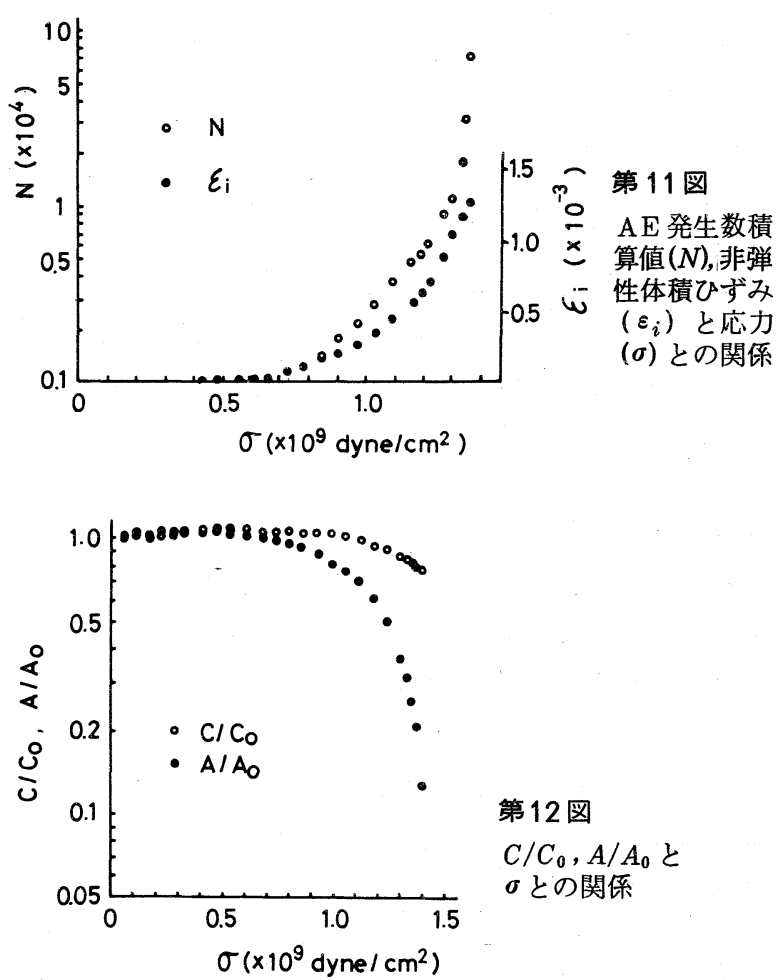

したものであり，第 10 図は鉱柱採掘終了後の昭和56年3 月 12 日に測定した波形の一例を示したものである。

\section{5. 考察}

現場測定結果とすでに公表した岩石試料を用いた室内実 験結果とを対比して検討する。

まず，以下に室内実験結果を簡単に示す。室内実験では $6 \mathrm{~cm} \times 6 \mathrm{~cm} \times 12 \mathrm{~cm}$ の花崗岩試料の側面に, 弾性波の伝 播にともなう振幅の減衰状態の変化执よび弾性波伝播速度 を測定するための 1 対の圧電素子, AE を検出するための 圧電素子, およびひずみを測定するための抵抗線ひずみゲ ージを貼り付けたものを，ひずみ速度一定で加圧する剛性 圧縮試験機を用いて加圧し, 応力とこれらとの間の関係に ついて検討した。

第 11 図は非弾性体積ひずみ $\varepsilon_{i}$, およびある基準值 ( 圧 電素子の出力信号を $50 \mathrm{~dB}$ 増幅したときの電圧が $250 \mathrm{mV}$ ) 以上の大きさの $\mathrm{AE}$ の発生数の積算値 $N$ と応力との関係を 示したものである。第 12 図は試験開始前の無荷重状態の ときのP波伝播速度 $C_{0}$ および試料内を通過してきた波動の 初動の振幅 $A_{0}$ で, 任意の応力状態のときのP 波速度 $C$ およ び初動の振幅 $A$ を除した $C / C_{0}, A / A_{0}$ の值と応力との関係 を示したものである。 AE の発生はマイクロクラックの発 生に対応しており, 非弾性体積ひずみの発生は花崗岩のよ うなぜ、性材料の場合には新たなき裂の発生または, 既存 のき裂の厚さの増大による間吵率の増加に対応していると みなしうる。このことを念頭において $C / C_{0}$ および $A / A_{0}$ の変化をみてみると， $A / A_{0}$ と $N$ および $\varepsilon_{i}$ とはかなりよく 対応しており，破壊荷重のほぼ $1 / 2$ の荷重付近から変化が
明膫に現われており，破壊に到るまでの変化も大きい。こ のことは, $A / A_{0}$ はマイクロクラックの発生に対してかな り敏感であることを示している。一方, $C / C_{0}$ の值は材料 内にかなりのマイクロクラックが発生していると考えられ る破壊応力のほぼ $70 \%$ 程度の応力値にならなければその 低下は現われず，破壊に到るまでの変化も少ない。

き裂を含む岩盤内の弾性波伝播速度および伝播にともな う振幅の減衰状態は，波動の伝播径路を横切つているき裂 の数, き裂の厚さ, 幅, 長さ, およびき裂内に存在してい る物質の特性によつて変化し, さらに振幅の減哀に関して は波動の波長とこれらとの関係によつても変化する。した がつて, 現時点では室内実験結果と現場測定結果とを定量 的に対比して検討することはできないが，定性的には対比 して検討しうると考えられる。

そこで，以上に示した室内実験結果を念頭に置きながら， 現場測定結果をみてみると, 鉱柱採掘によつて $-130 \mathrm{~m} レ$ ベルの岩盤内に新たなき裂の発生または既存のき裂の厚さ， 幅, 長さのいずれかの增大が発生したが，P波速度がほと んど変化していないことから考えて, 発生した現象は微細 なものであろうと考光られる。さらに， $A / A_{0}$ の值の低下 が徐々に少なくなつていることから考えて, 鉱柱採掘によ つて空洞天盤近傍の岩盤内に微細な变化が発生したが，こ の変化の進行はほぼ止り, 岩般は徐々に安定しできている ものとみなすことができる。

最後に第 9 図および第 10 図に示した鉱柱採掘前後の振 動波形を対比してみると，最高值を示す初動付近の波形の 変化は認められず, 最高值を示す位置も変化していないこ とがわかる。しかし，最高值以後の波形にはわずかではあ るが位相のずれてや波形の変化か認められる。このこともま た， $-130 \mathrm{~m}$ レベルに発生した変化が微細なものであるこ とを示しているものと考えることができる。

\section{6. 結言}

弾性波の伝播にともなう振幅の減衰状態の変化を測定す ることによつて岩盤監視を行なうための測定システムにつ いて検討し, 位相反転回路とピークホールド回路とを用い て振動の正のピークと負のピークとを検出する方式が現場 測定に適しているという結論を得た。そこで, 乾電池電源 の小型軽量な測定装置を試作し，これを用いて鉱柱採掘現 場の天盤近傍の岩盤の監視を行なつた。岩盤監視は伝播に ともなう振幅の減衰状態の変化のほかに, 弾性波伝播速度 の測定も併用して行なつた。その結果, 鉱柱採掘によつて 空洞天盤からほぼ $10 \mathrm{~m}$ 上部の岩盤内に生じた新たなき裂 の発生とか既存のき裂の厚さ, 幅, 長さの変化などの岩盤 内に発生した変化は微細なものであると推定できた。さら に, 振幅の低下の状況から採掘が終了しても岩盤の破壊が 進行しているのではなく，鉱柱が取り去られた状態で岩盤 が徐々に安定してきていると推定することができた。この 


\section{ことは岩盤監視という点から考えて重要な結果の一つであ る。}

最後にこの研究に対して種々の有益なご助言をいただい た京都大学工学部吉住永三郎教授に深く感謝する次第であ る。

\section{参考文 献}

1）伊藤一郎・佐々宏一・関 順一：き裂の存在および伸展にともなう, 弾性波伝播特性, 第 4 回岩の力学シンポジウム講演集, pp. 55 60 (1973)
2）井上博之・金子勝比古・佐々宏一・伊藤一郎：岩石の破壊の進展に 伴亏弾性波の減衰, 日本鉱業会誌, 94 巻, 1083 号, pp. 323 328 (1978)

3）金子勝比古・井上博之・佐々宏一・伊藤一郎：岩石の破壊の進展が 周波数の異なる波動に及ぼす影響について，日本鉱業会誌，94 巻， 1089 号, pp. 791 796 (1978)

4) K. Kaneko, H. I noue, K. Sassa, I. Ito : Monitoring the Stability of Rock Structures by means of Acoustic Wave Attenuation, Proc. 4 th Congress of International Society for Rock Mechanics, vol.2, pp. 287 292, (1979)

\title{
Rock Mass Inspection by Observation of Propagation Velocity and Attenuation of Sonic Waves
}

\author{
by Koichi SASSA ${ }^{1}$, Nobukazu NANKO ${ }^{2}$ and Takao SHIBUE ${ }^{2}$
}

It is very important for mine safety to inspect the rock mass around underground openings. In this study, the rock mass above the hanging wall which had been supported by the pillars was inspected with the progress of the mining of the pillars. The inspection was performed by monitoring the propagation velocity and the attenuation of the amplitude of the sonic wave through the rock mass. A portable equipment to observe a cracking in a rock mass by means of the change in the amplitude of sonic wave was made and used for the detection of crackings. The observation started before the beginning of the mining of the pillars and continued for about two years until the pillars were mined out. The experimental results are briefly shown below.

1) P wave velocity does not change throughout this experimental period.

2) The attenuation of the amplitude of the sonic wave increases in conjunction with the progress of the mining of the pillars, and the increase of the attenuation is going to stop when the pillars have been mined out and the opening area has been filled up with soil.

3) History of the attenuation shows that the rock mass under inspection settles under the condition that the pillars have been mined out.

深海底鉱物資源の開発をめぐる 内外の動き

\section{伊藤 福 夫 $^{*}$}

1973 年以来, 第 3 次国連海洋法会議 ${ }^{1)}$ において, 新しい海の秩序となる海洋法条 約草案について10年余の歳月をかけて審議 が続けられてきたが，第11会期最終日の 1982 年 4 月 30 日に, ようやく条約草案が 付帯の先行投資保護決議案等とともに投票に より賛成多数で採択された。ちなみに，賛 成 130 か国（日，仏，発展途上国など）， 反対 4 か国（米，ベネズェラ，トルコ，イ スラェル），棄権17加国（ソ連, 英, 西 独，スペイン，イタリヤ，東欧諸国など） であつた。今後, 条文上の整理が行なわれ た上, 今年 (1982 年) 12 月開催予定のカラ カス総会で，それぞれ条約および決議とし て採択されることになつている。このこと により, 永年懸案となつていた深海底鉱物 資源開発事業が国際機関が認めた形で発足 することになる。各国は遅くとも 1983 年 1月 1 日までに関連国内法を整備し, 各国 の深海鉱業者法各国政府に鉱区を供託して いることが要求され，これに間に合わない 者は乗り遅れることになる。すでに米国， $*$ 正会員 工博 公害資源研究所
西独, 英国, フランスおよびソ連ではそれ ぞれ 1980 年 6 月, 1980 年 8 月, 1981 年 7 月， 1981 年 12 月および 1982 年 4 月に国 内法が制定されている。わが国においても， 遅まきながら今年 5 月 14 日に「深海底鉱業 暫定措置法」が議院立法として衆議院を通 過, 7 月 9 日に参議院を通過して 7 月 20 日 に施行されており, 事業体として, 半官半 民（政府出資 $70 \%$ 以上）の「深海資源開発 株式会社」が 9 月16日付で設立された。

これで, 深海底のマンガン・ノジュール の開発は, 多くの制約がある ${ }^{2)}$ もの, い よいよ 1983 年から国連公認の探査活動を 皮切りに, 開発活動が開始されることにな るはずである。ここで，「なるはず」とと くにことわつたのは, いま, 気がかりな動 きのあることである。それは, 以前にもこ のページで述べたように ${ }^{2)} 1980$ 年の再開 第 9 会期で, 海洋法条約の公式草案を作成 するという当初の目標こそ達成されなかつ たものの，いくつかの難関を突破し，概ね 条約内容について会議参加国全体の合意が みられ，事実上終了していた。しかし，
1981 年 1 月, カーター政権からレーガン 政権に交代したとたんに，これまでの米国 の態度を $180^{\circ}$ 変えて,「米国内のレビュー 待ち」を理由に第10会期および再開第10会 期会議を完全に空転させた上，1982 年に 入つて, 全メンバーのほぼ合意を得たこれ までの条約草案を根本から変える提案をし これが受け入れられないとわかると, コー 議長の調停案をはねつけ, 全員一致の原則 を破つて投票採決に持ちこんだ。その結果 は，前述したとおりであり，深海底鉣物資 源開発の問題で反対したのは，米国唯一人 （他の 3 か国は大陸棚や国内事情によるも の)で，完敗を契した。これで納まらない 米国は, 英国, 西独, フランスに呼びかけ, 今年 9 月 2 日，ついに，4 か国で梁海底開 発をめぐる“ミニ条約”を調印締結した。 このことにより，圧倒的な賛成多数で採択 され，今年末のカラカスでの署名会議で発 足する予定の国連海洋法条約体制に重大な 問題を提記することになつたからである。

ともかくも，ここで改めて新しい海の秩 序と, マンガン・ノジュール開発のスキー 